\section{Ny ekkokardiografisk metode for å beregne hjertets arbeid}

\author{
Norske forskere har utviklet en ny ultralydbasert metode for å vurdere \\ regionalt og globalt arbeid i hjertet.
}

Å kvantifisere hjertets venstre ventrikkelfunksjon er en viktig del i vurderingen av pasienter med hjertesykdom. De siste årene har nye ultralydmetoder blitt introdusert for å kvantifisere global og regional ventrikkelfunksjon. Ved bruk av flekksporingsekkokardiografi (speckle tracking ekkokardiografi; STE) følges ekkogene punkter (flekker, speckles) i myokard og gir informasjon om regional og global kontraksjon som en prosent av hvilelengden.

Problemet med indekser basert på myokardial forkorting at de ikke gjenspeiler myokardialt arbeid eller oksygenetterspørsel. Dette skyldes at disse målene kun sier noe om graden av forkorting, men ikke motstanden som myokard må forkorte seg mot. Eksperimentelle studier har vist at man ved å kombinere informasjon fra venstre ventrikkel-trykk og regional deformasjon kan konstruere trykkdeformasjonssløyfer (loops), og at arealet av disse sløyfene gir informasjon som gjenspeiler regionalt slagarbeid og oksygenetterspørsel (1). Det lar seg ikke gjøre å måle invasive trykk i venstre ventrikkel på alle pasienter. Målet med denne studien var å introdusere en ikke-invasiv metode for å beregne hjertets arbeid (2).

- I denne studien kunne vi vise at regionalt arbeid kan beregnes ikke-invasivt ved hjelp av ultralydbasert flekksporingsekkokardiografi og en estimert venstre ventrikkeltrykk-kurve, sier førsteforfatter Kristoffer Russell. - Disse funnene korrelerte godt til beregninger gjort med invasive målinger. Vi validerte funnene $\mathrm{i}$ en eksperimentell dyremodell og i pasienter med invasive venstre ventrikkel-trykkmålinger. Videre kunne vi vise at den nye ikke-invasive metoden gjenspeilte regionalt glukoseopptak i hjertet ved hjelp av positronemisjonstomografi (PET), noe som er med på å styrke vår konklusjon om at denne metoden gjenspeiler regionalt arbeid, sier han,.

- Å kunne vurdere regionale forskjeller er spesielt viktig for pasienter med patologiske forandringer som ikke affiserer hele ventrikkelen likt, slik som iskemi og elektrisk dyssynkroni som ved venstre grenblokk. Denne metoden har derfor et stort potensial for bedre kvantifisering av denne store pasientgruppen, sier Russell.

\section{Hjertemekanikk og translasjonsforskning}

Artikkelens første- og annenforfattere,

Kristoffer Russell og Morten Eriksen,

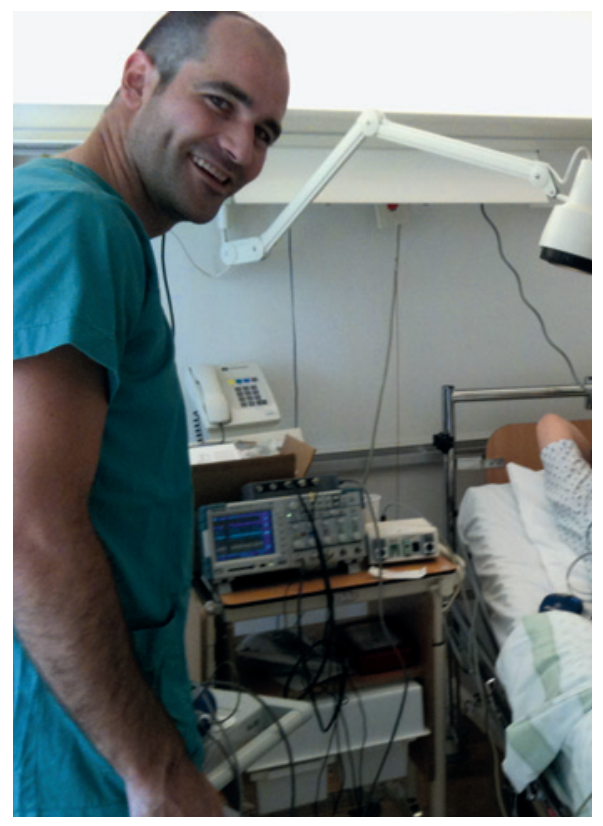

Førsteforfatter Kristoffer Russell. Foto Kristina H. Haugaa

er med i gruppen til Otto Smiseth ved Hjerte-, lunge- og karklinikken ved Oslo universitetssykehus. Forskergruppen arbeider med translasjonsforskning, noe denne studien er et eksempel på. Den eksperimentelle delen ble utført ved Institutt for kirurgisk forskning, som ledes av Ansgar O. Aasen. Pasientundersøkelsen ble gjort ved Kardiologisk avdeling under ledelse av Lars Aaberge, og PET-analysene ble utført på PET-senteret ved Oslo universitetssykehus, Rikshospitalet under ledelse av Jan Gunnar Fjeld. Metoden utvikles nå videre i det nyoppstartede Center for Cardiac Innovation ved Oslo universitetssykehus, Rikshospitalet, som ledes av Thor Edvardsen, i samarbeid med General Electric. Metoden vil bli en del av kommende analyseverktøy tilknyttet General Electrics ultralydmaskiner.

\section{Erlend Hem}

erlend.hem@medisin.uio.no

Tidsskriftet

\section{Litteratur}

1. Suga $H$. Total mechanical energy of a ventricle model and cardiac oxygen consumption. Am J Physiol 1979; 236: H498-505.

2. Russell $K$, Eriksen $M$, Aaberge $L$ et al. A novel clinical method for quantification of regional left ventricular pressure-strain loop area: a non-invasive index of myocardial work. Eur Heart J 2012; 33 . 724-33.
Ordforklaringer

Myokardial strain: Ekkokardiografisk metode som deler opp hjertekammeret i 16 segmenter. Den gir informasjon om hvordan et hjertesegment forkortes og forlenges i løpet av hjertesyklusen.

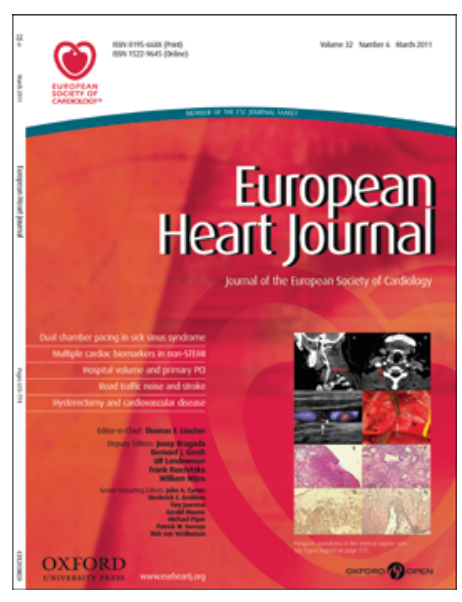

Artikkelen ble publisert i marsutgaven 2012 av European Heart Journal

(http://eurheartj.oxfordjournals.org), som er et av de høyest rangerte kardiologiske tidsskrifter. (C) Oxford University Press 